\title{
Modulation of DNA damage prevention and signaling pathways in diet induced colon cancer prevention
}

\author{
Dalila FN Pedro ${ }^{1 *}$, Alice A Ramos ${ }^{1}$, Cristóvão F Lima², Fátima Baltazar ${ }^{3}$, Cristina Pereira-Wilson ${ }^{1}$ \\ From 16th International Charles Heidelberger Symposium on Cancer Research \\ Coimbra, Portugal. 26-28 September 2010
}

Colorectal cancer (CRC) is a common malignancy and significant cause of mortality in Western societies. It develops through an accumulation of genetic and epigenetic alterations, transforming normal colon cells and giving them growth advantage. Epigenetic alterations are reversible and studies have shown that dietary compounds can alter the epigenetic status and reactivate epigenetically-silenced genes. Many food plants are rich in bioactive compounds and have shown to posses anticancer properties.

We proposed to explore the effects of sage (Salvia officinalis (SO)) water extract (herbal tea) drinking on colon cancer prevention and modulation of epigenetic events. F344 rats were used to study the effects of sage tea drinking on pre-initiation ( $\mathrm{SO}$ treatment before $\mathrm{AOM}$ exposure) and post-initiation (SO after AOM exposure) phases of carcinogenesis. We found a chemopreventive effect of $\mathrm{SO}$ in the pre-initiation group, but not in the post-initiation. We then investigated if $\mathrm{SO}$ affected AOM metabolism, searching for effects on CYP2E1 expression and activity. We found that AOM decreased CYP2E1 activity when compared with control, but SO treatment before AOM prevented this effect. The capacity of $\mathrm{SO}$ in vivo treatment to protect colonocytes from $\mathrm{H}_{2} \mathrm{O}_{2}$ damage induced in vitro was also investigated. $\mathrm{SO}$ decreased significantly the oxidative $\mathrm{H}_{2} \mathrm{O}_{2}$-induced DNA damage. We also are searching for alterations in expression of key proteins involved in signalling pathways important for cell proliferation or apoptosis and proteins involved in DNA repair.

* Correspondence: daliped@hotmail.com

'CBMA, Department of Biology, University of Minho, Braga, Portugal

Full list of author information is available at the end of the article
Sage water extract seems to have the ability to prevent $\mathrm{CRC}$ and studies to further explore this potential are ongoing.

\section{Author details}

'CBMA, Department of Biology, University of Minho, Braga, Portugal. ${ }^{2} \mathrm{CITAB}$, Department of Biology, University of Minho, Braga, Portugal. ${ }^{3}$ ICVS - Life and Health Sciences Research Institute, University of Minho, Braga, Portugal.

Published: 24 September 2010

doi:

Cite this article as: Pedro et al:: Modulation of DNA damage prevention and signaling pathways in diet induced colon cancer prevention. $B M C$ Proceedings 2010 4(Suppl 2):P58.
Submit your next manuscript to BioMed Central and take full advantage of:

- Convenient online submission

- Thorough peer review

- No space constraints or color figure charges

- Immediate publication on acceptance

- Inclusion in PubMled, CAS, Scopus and Google Scholar

- Research which is freely available for redistribution

Submit your manuscript at www.biomedcentral.com/submit
C Biomed Central 